\title{
An Evaluation of the Sustainable Community Development of Pig Farming, under the Serasah System, in Wonosobo Regency, Indonesia
}

\author{
Yans Pangerungan ${ }^{1}$, Suci Paramitasari Syahlani ${ }^{1} \&$ F. Trisakti Haryadi ${ }^{1}$ \\ ${ }^{1}$ Gadjah Mada University, Yogyakarta, Indonesia \\ Correspondence: Suci Paramitasari Syahlani, Gadjah Mada University, Fauna Street 3, Yogyakarta, Indonesia. \\ E-mail: suci.syahlani@ugm.ac.id
}

Received: September 4, 2016

doi:10.5539/jsd.v10n3p231

\author{
Accepted: September 17, $2016 \quad$ Online Published: May 31, 2017 \\ URL: https://doi.org/10.5539/jsd.v10n3p231
}

\begin{abstract}
The purpose of this research is to evaluate the level of sustainability of pig farming,under the serasah system in Wonosobo Regency, Indonesia. This research is conducted in six villages located in the District of Kertek, the six village are Candimulyo, Candiyasan, Kapencar, Pagerejo, Purbosono, and Reco. The research's activities are carried out in three phases: Preparation, data collection, and analysis. The preparation phase includes the collection of information from the reference sources required to initiate the research. The data collections' phase, to obtain the primary data on theserasah system of pig farming, use the observation method, in-depth interviews and surveys via a questionnaire to identify the factors that contribute to the sustainability of pig farming within theserasah system. The in-depth interviews include talks with key figures in the villages'serasahpig farming system. The next stage is the processing of the data by analyzing every aspect of it. Based on the results of the assessment of the level of sustainability of pig farming in Wonosobo, the ecological aspect's percentage is lower than that of the socio-economic aspects. The socio-economic aspects are showing progress towards sustainability, and the ecological aspects indicate they have made a good start towards sustainability. In other word serasah system pig farms have a good sustainability as farm business activities.
\end{abstract}

Keywords: sustainability, ecological, socio-economic, Serasah system

\section{Introduction}

Piggeriesin Muslim country where pork consumption is a religious taboo to consumed face difficulties to be sustained. Nonetheless, Table 1 shows that from 2012 to 2013 the number of pig farms in the Indonesian Provinces increased with an average growth rate of less than 5\%, except for Maluku. Maluku is the only island with the high growth rate that is $12.56 \%$, since the majority of Maluku population are not Muslim. This growth shows that this type of farming can still be sustained in Indonesia, despite the Muslim majority population.

Table 1. Number of pig farms in Indonesia from 2012 until 2013

\begin{tabular}{llll}
\hline Island & 2012 & 2013 & Average Growth (\%) \\
\hline Sumatra & $1,099,800$ & $1,139,170$ & 3.58 \\
Java & 194,100 & 195,300 & 0.62 \\
Bali & 922,900 & 930,500 & 0.82 \\
Nusa Tenggara & $1,777,100$ & $1,837,800$ & 3.42 \\
Kalimantan & $1,042,700$ & $1,087,200$ & 4.27 \\
Sulawesi & $1,393,900$ & $1,418,600$ & 1.77 \\
Maluku & 269,200 & 303,000 & 12.56 \\
Papua & 600,700 & 613,900 & 2.19 \\
\hline
\end{tabular}

Source: Ministry of Agriculture (2014)

Pig farming is the rearing of pigs for their meat. Pigs can be bred in fields, in a traditional sty, or in a modern sty. 
Traditional sties for pigs are disappearing and the current trend is to use more intensive methods and modern pigsties. The majority of pig farms maintain more than 5,000 individual animals in their buildings and 100 million pigs are slaughtered each year (Brown, 2001).

A pig is the most efficient animal at converting feed into meat with a feed conversion ratio, between 3.4 to $3.6 \mathrm{~kg}$, which means that for every $3.6 \mathrm{~kg}$ of feed given to a pig, it will produce a piece of meat weighing $1 \mathrm{~kg}$. Breeding pigs is also profitable, compared to other animals, because have a high reproductive rate, producing an average litter size of 7-11 piglets per pregnancy. However, due to the religious factor which puts obstacles in the way of developing this type of farming, the consumer segment is quite limited, and this type of farming does need a lot of water (Sihombing, 2006).

Wonosobo Regency is a mountainous area on the slopes of Mounts Sindoro and Sumbing. Pig farming in Wonosobo Regency is concentrated in Kertek District. Working as a pig farmer often creates controversy from the perspective of the pig farms' numbers, the local society, and the religious aspect. However, it is unique that pig farms still survive to this day under the serasah system,even though the majority of the population in Kertek is Muslim as shown that the number of pigs in Wonosobo Regency in 2013 still high, that was 2,135 tails (Department of Animal Husbandry, Wonosobo Regency, 2014). It may because a by-product of pig farming is the production of compost by the pig farmers is used as the best fertiliser among other types of fertiliser on tobacco plantations or similar enterprises.

Serasah system is an traditional form of pig farming by impounding 2-3 pigs in a $2 \times 3$ meter cage made from bamboo/wood or combination of both and a pedestal cage within 2 meters off the ground so that dirt can fall and be accumulated on the ground. Pigs are fed with vegetables remaining from local agricultural land not qualified to be sold. In the process of composting, dried leaf and twigs are added to reduce feces odors (Hartoko, 1988). Pig farming under the serasah system is a way of farming that is easy and can reduce environmental pollution. This system was developed to allow pigs to be kept near thefarmers' houses, and is the typical system for pig farms in Indonesia. Usually the farm includes a building containing the pigs' sties, which is located near the area of the domestic dwellings, and the pigs are left alone in their sties until their faeces pile up as high as \pm 1.5 meters, when it is removed. Other distinctive features of the serasah system of pig farming is in its water saving, as it uses less water than other systems, it is also flexible in terms of the working hours required to run it, the smell of faeces at the sties' location is not really strong, and the faeces are collected and dealt with.

Pig faeces potentially could contaminate settlements, but the farmers avoid this by processing their swine's' waste into compost which is then sold. The waste is processed to prevent pollution and to generate income by selling it as fertilizer to local farms and plantations. This is a form of maintaning ecovillage; connecting individual to the social and ecological worlds that are being mutually and reciprocally transformed through day to day lived experience (Kirby, 2001). The advantages to raising pigs under the serasah system include the acceptance of the industry by people from the surrounding area, the ease of obtaining a license to build a pig farm in the villages, they are safe from thieves, not time-consuming to run, and they are cheap and practical (Hartoko, 1988).

The ecological and socio-economic sustainability of the serasah system of pig farming needs to be investigated so that it can be better understood, and the extent of its sustainability in Wonosobo Regency be evaluated. Analysis the ecological and socio economic sustainability conducted by using Community Sustainability Assesment that developed by Global Ecovillage Network. Ecovillage builds connectedness of the individual to the social and ecological worlds to be sustained in the future. The level of sustainability of a community that consist three indicators that are spiritual, ecological and socio-economic (Global Ecovillage Network, 2000).

\section{Method}

As a first step information was gathered through a search of the relevant reference document and secondary data, mainly obtained from some of the parties involved in the research. Collected information included conditions of various research sites, knowledge of local culture, and behavior patterns of the farmers.

Primary data were collected to identify rural conditions in Wonosobo Regency and provide an assessment of the level ofsustainability of theserasah system of pig farming. Information on climate, soils and topographyof the surveyed sites wasalso collected, to gauge the sustainability in the form of its physical and biophysical concepts(Frick and Suskiyatno, 2007). The method used was a direct observation of the research site.

Location of the research can be seen in Figure 1. 

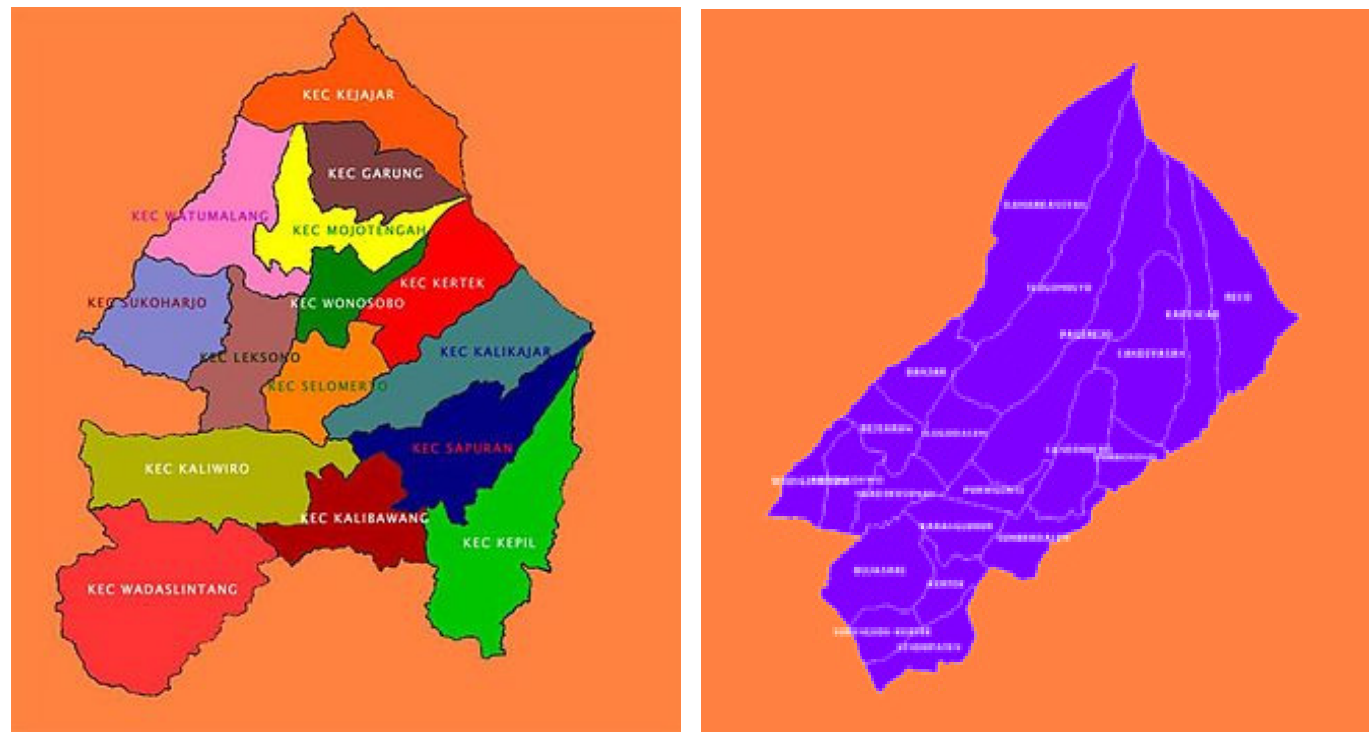

Figure 1. Wonosobo Regency (Left) and the location of pig farms operating with the serasah system (Right) in Kertek District

We aimed to interview $25 \%$ of the total number of pig farmers in each community, which is deemed sufficient to represent the total population for descriptive research (Gay and Diehl, 1992). The number of pig farmers in each community is reported in Table 2. Respondents were selected by random sampling. Three fish farmers were interviewed in Candimulyo and Pagerejo villages, six in Purbosono village, 13 in Kapencar village, 22 and 24 in Candiyasan and Reco villages, respectively. The total number of respondents in main study were 71.

Table 2. Total respondents

\begin{tabular}{llll}
\hline Villages & Number of Pigs & Number of Farmers & $\begin{array}{c}\text { Number of interviewed farmers } \\
\text { (approx. 25\%) }\end{array}$ \\
\hline Candimulyo & 18 & 11 & 3 \\
Purbosono & 107 & 24 & 6 \\
Kapencar & 593 & 49 & 13 \\
Candiyasan & 632 & 86 & 22 \\
Pagerejo & 31 & 12 & 3 \\
Reco & 754 & 96 & 24 \\
\hline Total & 2,135 & 278 & 71 \\
\hline
\end{tabular}

Source: Central Agency of Statistics, Wonosobo (2014)

Table 3. Indicators of the ecological and socio-economic sustainability

\begin{tabular}{ll}
\hline Ecological indicators & Socio-economic indicators \\
\hline Sense of place and location & Openness, trust, and security \\
Availability, production, and distribution of food & Communication and information \\
Infrastructure, buildings, and transportation & Networks and services \\
Patterns of consumption and solid waste management & Social sustainability \\
Water, its quality and usage patterns & Education \\
Waste management and water pollution & Economic sustainability \\
\hline
\end{tabular}

Source: Global Ecovillage Network (2000) 
The level of sustainability of each individual ecological and socio-economic indicator was assessed based on the average total score from the questionnaire's results. This average total score was estimated by dividing the average scores from the questionnaires by the highest score from the questionnaire and then multiplying that by 100 , to get a percentage figure. Details of the calculation are as follows:

$$
\frac{\text { Average score }}{\text { Highest score }} \times 100 \%
$$

The sustainability criteria's value can be expressed as a percentage figure, which is found by subtracting the minimum percentage from the maximum percentage, and then dividing that by the number of categories. Details of the calculation are as follows:

$$
\text { Percentage of sustainability criteria }=\frac{\text { Maximum percentage }- \text { Minimum percentage }}{\text { Number of categories }}
$$

$$
\text { Percentage of sustainability criteria }=\frac{100-0}{3}=33.3
$$

The farms' sustainability criteria are as follows:

$66.7-100$ percent: Shows progress towards sustainability.

$33.4-66.6$ percent: Indicates a good start towards sustainability.

$0-33.3$ percent: Indicates the need for further action to achieve sustainability.

The rural conditions in Wonosobo Regency were analyzed by comparing the circumstances present there in accordance with the standards to achieve a sustainable farm based reference. An assessment of the level of the sustainability of the serasah system's pig farming is reached by analyzing the material in the questionnaire, which outlines all the potential benefits and the constraints of pig farming using the serasah system.

A questionnaire is essential in collecting data, but the questionnaire should be tested before being used in research, in order to determine the levels of its validity and reliability. Testing the discriminant validity refers to the extent to which an instrument can perform its function. Reliability is consistancy, in this case a questionnaire as a tool, measure what needs to be measured. Cronbach Alpha was used as reliability test. It is reliable if, whenever the tool is used, it provides the same measurement or results (Cooper and Schlinder, 2011). Reliabit

The formulas for the validity and reliability are as follows:

$$
\begin{gathered}
\text { Validity } \\
r_{x y}=\frac{N \sum X Y-\left(\sum X\right)\left(\sum Y\right)}{\sqrt{\left\{N \sum X^{2}-\left(\sum X\right)^{2}\right\}\left\{N \sum Y^{2}-\left(\sum Y\right)^{2}\right\}}}
\end{gathered}
$$

Description:

rxy: Correlation coefficient

$\Sigma Y$ : Total score

$\Sigma \mathrm{X}$ : Total score of item

$\mathrm{N}$ : Number of samples

$$
\begin{gathered}
\text { Reliability } \\
r_{11}=\left[\frac{n}{(n-1)}\right]\left[1-\frac{\sum \sigma_{i}^{2}}{\sigma_{t}^{2}}\right]
\end{gathered}
$$

Description:

$\sigma 2$ : Variance items

$\sigma 2 \mathrm{t}$ : Variance total score

n: Number of items

The validity measurements are carried out by using the Statistical Product and Service Solutions (SPSS) for 
Windows Version 16.0, by looking at the corrected items total value for each item.If the correlation in question has a negative value, or the correlation's value is smaller than the value of $r$ in the table, it can be said to be invalid. A test for the validity of using a bivariate correlation is done by employing Pearson's correlation, so that the results from pilot test with 21 of the respondents, can be seen in Tables 4 and 5. Valid items from the 21 respondents have a value of $r \geq 0.433$.

Table 4. The validity of the test results of the ecological aspects

\begin{tabular}{|c|c|c|c|c|c|c|c|}
\hline \multirow{2}{*}{ Variable } & \multicolumn{7}{|c|}{ Item } \\
\hline & 1 & 2 & 3 & 4 & 5 & 6 & 7 \\
\hline Sense of place and location & $0.433^{*}$ & $0.597^{*}$ & $0.466^{*}$ & $0.436^{*}$ & 0.410 & $0.436^{*}$ & $0.527^{*}$ \\
\hline $\begin{array}{l}\text { Availability, production, } \\
\text { distribution of food }\end{array}$ & $0.624 *$ & $0.550^{*}$ & $0.478^{*}$ & $0.444^{*}$ & - & - & - \\
\hline $\begin{array}{l}\text { Infrastructure, buildings, } \\
\text { transportation }\end{array}$ & $0.672 *$ & $0.518^{*}$ & $0.573^{*}$ & $0.575^{*}$ & $0.444^{*}$ & $0.607^{*}$ & - \\
\hline $\begin{array}{l}\text { Patterns of consumption and solid } \\
\text { waste management }\end{array}$ & 0.213 & $0.505^{*}$ & $0.756^{*}$ & $0.527^{*}$ & - & - & - \\
\hline Water, its quality and usage patterns & $0.478 *$ & 0.158 & $0.557^{*}$ & $0.672 *$ & $0.710^{*}$ & - & - \\
\hline $\begin{array}{l}\text { Waste management and water } \\
\text { pollution }\end{array}$ & $0.608 *$ & $0.494 *$ & $0.807^{*}$ & $0.717^{*}$ & - & - & - \\
\hline
\end{tabular}

Description: $*=$ Correlation is significant at the 0.05 level (2-tailed).

Table 5. The validity of the test results of the socio-economic aspects

\begin{tabular}{lccccc}
\hline \multicolumn{1}{c}{ Variable } & \multicolumn{3}{c}{ Item } \\
\cline { 2 - 5 } & 1 & 2 & 3 & 4 & 5 \\
\hline Openness, trust, and security & $0.722^{*}$ & $0.538^{*}$ & $0.797 *$ & $0.702^{*}$ & - \\
Communication and information & $0.580^{*}$ & $0.475^{*}$ & $0.901^{*}$ & - & - \\
Networks and services & $0.804^{*}$ & $0.709 *$ & $0.552^{*}$ & - & - \\
Social sustainability & $0.596^{*}$ & 0.082 & $0.745^{*}$ & $0.512^{*}$ & $0.618^{*}$ \\
Education & $0.693^{*}$ & $0.643 *$ & $0.475^{*}$ & - & - \\
Economic sustainability & $0.650^{*}$ & $0.702 *$ & $0.867 *$ & $0.433^{*}$ & - \\
\hline
\end{tabular}

Description: $*=$ Correlation is significant at the 0.05 level (2-tailed).

Table 6. Reliability test results of the ecological aspects

\begin{tabular}{|c|c|c|c|}
\hline Variable & Cronbach Alpha & Limitation & Reliability \\
\hline Sense of place and location & 0.684 & 0.60 & Reliable \\
\hline The availability, production, and distribution of food & 0.654 & 0.60 & Reliable \\
\hline Infrastructure, buildings, and transportation & 0.718 & 0.60 & Reliable \\
\hline Patterns of consumption and solid waste management & 0.646 & 0.60 & Reliable \\
\hline Water, its quality and usage patterns & 0.635 & 0.60 & Reliable \\
\hline Waste management and water pollution & 0.688 & 0.60 & Reliable \\
\hline
\end{tabular}


Table 7. Reliability test results of the socio-economic aspects

\begin{tabular}{llll}
\hline Variable & Cronbach Alpha & Limitation & Reliability \\
\hline Openness, trust, and security & 0.742 & 0.60 & Reliable \\
Communication and information & 0.755 & 0.60 & Reliable \\
Networks and services & 0.739 & 0.60 & Reliable \\
Social sustainability & 0.689 & 0.60 & Reliable \\
Education & 0.658 & 0.60 & Reliable \\
Economic sustainability & 0.601 & 0.60 & Reliable \\
\hline
\end{tabular}

\section{Result}

\subsection{Description of Rural Conditions in Wonosobo Regency}

One of the requirements forrunning a farm is to know the condition of the surrounding countryside. It is beneficial to know the type of farming which is best suited to that particular land area, so it can be farmed properly (Makermann et al., 2009).

The soil in the regency is either the red latosol or brown latosol soil (Central Agency of Statistics, Wonosobo, 2014). According to Soepraptohardjo (1976), brown latosol soil has adequate water retention capabilities, suitable levels of natural nitrogen, phosphorus and potassium (NPK), and fertilizer can be used to increase its productivity. At our research site, the red and brown latosol soils are used for rice production or as moorland. Red latosol soil has good physical properties and tends to be found on the oldest land. While the brown latosolssoil has a sandy texture similar to quartz sand. Wonosobo Regency isclassed as a region with a cold climate. According to Simond and Starke (2006), the characteristics of cold climates is they have low temperatures and relatively constant humidity and high rainfall, winds classed as breezes but can be stronger and there is a risk of hurricanes and storms, vegetation cover ranging from sparse to jungle, little solar radiation, and insect are abundant and that all factors are prone to fungal problems in that area.

According to Newman and Jennings (2008), biodiversity is the diversity of life on the planet and the natural patterns that shape it. Biodiversity includes a broad range of species, genetic variations and ecosystems in places. Biodiversity forms part of the characteristics of many of the landscapes. At the research sites there are diverse forms of biodiversity. On a smaller scale, it can be seen that different altitudes affects the biodiversity.

Vegetation at the research site's location is generally either that found on forest land or where agriculture is carried out. On any land planned for use, widevarieties of different types of plants can be found. At this time nearly 20,000 ha of land is classed as forest land in Wonosobo Regency, and almost the entire forest is in Kertek District because it is located on the slopes of Mounts Sindoro and Sumbing. This 20,000 ha area is 10 percent of the total forest area in the whole of Central Java. The existence of the forest, apart from its economic value, is very important as it is the local agriculture's support system, its buffer ecosystem, it guards the ecological stability of the area, and regulates the water system for the area of Kertek District.

\subsection{Serasah System Pig Farming in the Wonosobo Regency}

Raising pigs under theserasah system includeskeeping the pigs inserasahcompliant sties. Throughout the year the pigsare confined in sties continuously, without being able to bathe or wallow. The pigs only getwashed when the compost is harvested. Every day the pigs are fed forage from the rest of the agricultural produce, and hay. The aim of giving them dry grass is to not tarnish the sties' floors. In addition to hay, dried corn leaves are also fed to them.

Thisserasahsystem is also used by pig farmers in Papua New Guinea and in Hong Kong because of its low costs. According to Chan et al. (1994) sawdust is used to absorb water/urine in the pigsties so that they does not get wet or muddy. This agreeswith Watt and Michell (1989),who state thatdried kunai grass, sawdust, nut shells and coffee bean shellscan be used to absorb water/urine in a sty's enclosure. The heat that is formed from the provisioning of the dry kunai grass, sawdust, peanut shells, and the shells of coffee beans will accelerate the formation of a good compost.

\subsection{Sustanaibility Analysis of Serasah System Pig Farms}

The ecological aspects represent a good start towards sustainability, with a percentage figure of 65.1 percent. Table 8 is an assessment ofthe sub-ecological aspects. 
Table 8. Level of sustainability of the ecological aspects

\begin{tabular}{llll}
\hline Sub Aspects & High Score & Average Score & Percentage (\%) \\
\hline Sense of place and location & 25 & 16.2 & 64.8 \\
Availability, production, and distribution of food & 14 & 12.5 & 89.6 \\
Infrastructure, building, and transportation & 21 & 16.9 & 80.8 \\
Resource usage and solid waste management & 28 & 16.2 & 57.7 \\
Waterquality and usage & 23 & 9.2 & 40.0 \\
Waste and water pollution management & 13 & 9.7 & 74.9 \\
\hline Total & 124 & 80.7 & 65.1 \\
\hline
\end{tabular}

Description of percentage:

$66.7-100$ percent: Shows progress towards sustainability.

$33.4-66.6$ percent: Indicates a good start towards sustainability.

$0-33.3$ percent: Indicates the need for further action to achieve sustainability.

Table 9. Levels of sustainability of thesocial and economic aspects

\begin{tabular}{llll}
\hline Sub Aspects & High Score & Average Score & Percentage (\%) \\
\hline Openness, trust, and security & 16 & 15.2 & 95.3 \\
Communication and information & 23 & 14.3 & 62.3 \\
Networks and services & 13 & 11.9 & 91.7 \\
Social sustainability & 15 & 12.4 & 82.8 \\
Education & 11 & 9.6 & 87.6 \\
Economic sustainability & 16 & 9.7 & 60.7 \\
\hline Total & 94 & 73.1 & 77.8 \\
\hline
\end{tabular}

Description of percentage:

$66.7-100$ percent: Shows progress toward sustainability.

$33.4-66.6$ percent: Indicates a good start towards sustainability.

$0-33.3$ percent: Indicates the need for further action to achieve sustainability.

\section{Discussion}

Piggeries affect ecological and socio economic aspects of the village.Piggeries management that are not managed properly can violate on the environmental aspects of ecology and socio economic that will ultimately threaten the sustainability of piggeries. Table 8 shows that score of ecological aspects rating are good, that indicates "a good start toward sustainability". Then Table 9 shows that socio economic aspects have the best category that "it shows progress toward sustainability". These results indicate that Serasah system pig farmis able to overcome the negative impact of piggeries on the environment.

\subsection{Ecological Aspects}

The sub-aspect of thesense of place and location shows a good start towards sustainability with a percentage of 64.8 percent (Table 8). This sense of place and location are very important for sustainability because if the farmers living in the villages feel at home there, they have a sense of belonging, as well as an obligation or responsibility to maintain the land and thus improve the sustainability.

Farmers claim that fertile soils are only found in the agricultural production areas, which cover 46 percent of the total land area, and not throughout the region as a whole. In general, fertile soils, in addition to being in the agricultural areas, can also be found in the village or settlement areas too, but their spread there is uneven. This 
is evidenced by the tree planting undertaken by the farmers, which mostly grow to create a beautiful environment in the villages. Soil fertility is unevenly spread, because only the land in agricultural production areas is cultivated.

The size of the properties the farmers live in are largely the same. This is due to the uniformity of the shapes and styles of their residences. Simple life principles were passed down by their ancestors, who made the size of the properties very similar, so today's farmers do not have a sense of envy because they all have the same.

The sub-aspect of the availability, production, and distribution of food shows progress towards sustainability with a percentage figure of 89.6 (Table 8). Most farmers who work as farmers also have a rice field/plantation and harvest the produce from their rice field/plantation for their own consumption, so that their staple food needs are fulfilled.

The farmers claim that 92 percent of them do not use pesticides, herbicides, and chemical fertilizers, as they already implement a system of organic farming, while the other 8 percent answered that they very rarely used chemical fertilizers. According to Sudradjat (2006) there are several advantages to be gained from the use of organic agricultural products, including the fact that they do not contain pesticides, their effect on the environment is better because they protect the land from chemical contamination, they improve the soil's fertility and the physical properties of the soil's chemistry, and improve the protection of plants against pests and diseases.

Food is necessary for human life because the energy needed for the body's metabolism comes from the food we eat. The kitchen is the place for the preparation of food and drinks, but attention needs to be paid to hygiene and sanitation in there to prevent the contamination of cooked or raw foods and drinks. Food and drinks that are not kept clean will damage the health of those who eat them. Our results show 80 percent of the kitchens reach a state that is clean and only $20 \%$ are classed as less clean. The state of their kitchens indicates that the farmers pay attention to cleanliness in the process of cooking and making their food and drinks.

The sub-aspect of infrastructure, buildings, and transportation shows progress towards sustainability with a percentage figure of 80.8. This sub-aspect's figure is based on the availability of shelter, the level of use of building materials, the buildings' harmony with the natural environment and culture that exists there, and the availability and use of transport and the mobility of the farmers. Based on the ecovillage concept, all the buildings and construction work should be designed to be in harmony with nature, both in the choice of the materials used, the design, and the pattern of the buildings' placement. The materials used must also be natural and fit the local ecology.

Eighty-six percent of the farmers agree that there is suitable housing and adequate Serasah piggeries available, and they are protected from crime. Almost all the buildings, houses and enclosures are of the same pattern, both in their design, the materials used in their construction, and their layout. The houses are made in thejoglostyle and their walls are slightly perforated to allow for ventilation, and made of wood. Ecologically this is very good because of the flow of air around the buildings, and it helps to maintain the stability of the moisture in the ground (Frick dan Suskiyatno, 2007).

Sixty percent of the farmers explained that the division of the land into areas for crop production and settlement had not been neatly arranged and needs realigning by the local government,with only a few settlements arranged properly. The arrangement of the land is intended to make the locations neat and tidy, which enhances the conservation of the local environment and makes the villages more beautiful. Structuring the function of the land areas correctly for crop production, housing, and serasah pigsties is perceived as necessary by the majority of the public, as well as the farmers, especially arranging that theserasah pigstiesare adjacent to the houses' kitchens. Building the sties close to the kitchen is to prevent the pigs from being stolen. The farmers disagree on the reason why pigs may be stolen, because the farmers' residences are includedin a secure area, and according to 86 percent of the farmers, there is almost no cattle theft in their area. The farmers want to organize and classify their pig farms under theserasah system, so they can be kept neat and can enhance the conservation of the environment, which they hope will mean they can progress into agroforestry.

The layout of the buildings has them facing towards the northwest. According to Frick and Suskiyatno (2007), north facing buildings are not sited in an ideal position, as theyshould be facing to the east orwest. Buildings facing west obtain direct solar radiation from noon until the late afternoon (01.00 PM-04.00 PM) because in the morning the sun is in the east. Whereas in the morning, buildings facing west do not get direct solar radiation. Buildings facing east obtain direct solar radiation in the morning because the sun rises in the east. While during the afternoon they do not get direct solar radiation as the sun is in the west. This occurs throughout the year, and buildings facing north or south do not receive direct solar radiation throughout the whole year. This agreeswith 
Sukawi (2010), who states that buildings facing east or west are preferable than buildings facing north or south because they will get the intense sunlight at sunrise (for the buildings facing east) and sunset (for the west facing ones). But according to the farmers, the siting of the houses in the village has not changed since the days of their ancestors. Although the farmers' homes are built facing north, they still consider the intensity of the solar radiation on the buildings.

The sub-aspect of the resource usage and the solid waste's management is affected by how the solid waste is generated and how the system is managed. The ideal ecological system is to minimize the solid waste generated and use resources and facilities wisely by purchasing them together. However the score of this sub aspects is 57.7 percent (Table 8), since almost none of resources and facilities are use together by farmers as well as solid management both from household and farms are not managed well.

The consumption patterns of the farmers relatively simple. Their food is mostly derived from their own work. Staple foods such as rice or vegetables are grown by the farmers themselves. For those farmers who do not have fields, produce is available to buy at the local market, so their food needs are always fulfilled. In addition, their ancestors emphasised the principles of a simple life, which is why the consumption patterns of the farmers and villagers are quite simple.

The use of the available resources and facilities, and their joint purchase if required, is intended to minimize consumption and the generation of waste.The use of shared facilities is, however, limited to the mosque, the meeting room in the village hall, the communal bathroom, and an open field in the middle of village. Almost all the farmers have their own arable land, which they use to grow their own food on, any excess is sold to allow them to buy what they do not grow themselves, so they can meet their own or their family's necessary requirements, without needing to share resources.

The management of the solid waste originating from the pigs' faeces is good enough, because the pigs' faeces are collected and deposited in the stable. This solid wasteis then turned into compost which can either be used by the farmers themselves as fertilizer, or sold to other farms or plantations. Theserasah system makes the composting of pig faeces practical and easy. The faeces is stored and left alone, with no treatment, because it will automatically biodegrade into compost in about four months.

Waste management is important howeverawareness of, and concern for, the problems of waste is still lacking. Communal waste management systems are not found in the villages. Waste management occurs in the households,but in general they do not have a solid waste management system. Organic waste (leaves) and inorganic matter (plastics, glass) are usually just burned. Leftover or rotten food is given to pigs as part of their feed. Various agencies need to look into maximizing the waste management processes, and look further intothe problems of waste and its solutions, so that the sustainability of the sub-aspect of the patterns of consumption and solid waste management can be improved and maintained.

Forty percent of the farmers think that progress in the sustainability of the sub-aspect of water, its quality and usage patterns is being made (Table 8).The farmers know, respect, and protect the water sources they use, which are mostly from wells, which have water channels to direct water towards the farmers' homes. This water is used by the farmers for drinking, bathing, washing, and for their agricultural or plantation needs. The weakness of well water is that it is sometimes clean, sometimes murky, and in the dry season their wells can recede and the farmers will be short of water. Distances between the pigsties, wells, and septic tanks are not great, especially if near the kitchen, but thisis only in a minority of cases. There is a risk of contaminating the water supplied to the farmers' houses.

The water is sometimes murky and requires filtering before use. During the dry season and at other times of water shortages, the farmers and villagers take water from the Serayu River by using a pipe, to use for irrigation and for their homes. The lack of clean water in the village means counselling and discussions to show the importance of clean water for the health of the people is information that the farmers need to gain, so as to improve their health.

The sub-aspect of waste management and water pollution scored 74.9 percent from the farmers, which indicates progress toward sustainability is being made (Table 8). Waste produced by the farmers comes from their bathrooms, fish ponds and rice fields. Wastewater from their showers is usually the residual water from bathing, washing clothes, and wastewater from their toilet. Waste from the toilet is dumped straight into the fish ponds and this does not undergo any screening or testing and cleaning. This waste from the bathroomsis used to feed the fish in the ponds, and the water from the fish ponds may be used for watering plants. However, some houses already built septic tanks to process waste to process toilet waste. Although some residents have changed their ways, there are still a few who dispose of their waste in the nearby River Serayu.Seventy-six percent of the 
farmers state they already know how to manage waste properly. In addition to wastewater from their bathrooms, thefaecal waste from the pigs is managed well, by using theserasah system's enclosures. The use of pigsties makes the faeces of the pigs easy to collect, and after it is processed and biodegrades into serasah compost, it has a 100 percent positive effect on the growth of plants when used as fertilizer, according to the farmers. This shows that the sub-aspect of waste management and water pollution is progressing toward sustainability.

\subsection{Socio-economic Aspects}

The sub-aspect of openness, trust, and security shows progress towards sustainability with a score of 95.3 percent (Table 9). This sub-aspect reflects the farmers' feelings of mutual trust and safety in their own environment, creating a feeling of mutual support. In addition to the ecovillage concept, there is a support activity for this too.

Sixty-six percent of the farmers state that openness and trust between the farmers and villagers creates harmony in the village. This is due to the fact that all the members of the village society, including the farmers, live in the village and all have the same lineage. While 34 percent of the farmers say they still put their trust in other farmers, 98 percent of the public support all the activities of theserasah system pig farmers in the village. Based on the security aspect, 78 percent of farmers declare the villages are safe enough for the farmers and their families, and there is no crime. The other 22 percent said there is very little criminal activity,and although there is the occasional theft, the thieves only normally take the clothes hanging up outside on a clothesline. The pigs are considered to be very safe and there is no record of crimes against them. The farmers are committed to the security system in place, in which they take turns patrolling the village.

The sub-aspect of communication and information indicates a good start toward sustainability with a percentage score of 62.3 percent (Table 9). The farmers have the freedom to convey information and ideas through a variety of ways, such as the announcement of social events and meetings, but the system for the exchange of information between the farmers can be indirect and somewhat irregular. Exchanges of information seem only to be carried out at certain moments, sincethere is no specific timetable for the exchange of information, except in the event of significant problems occurring in the village.

The use of advanced technology such as the telephone and the Internet for communicating and disseminating information is also quite good.Regular meeting that arranged by government regularly for farmers and extension workers is the suitable medium to share any relevant information and discussing any issues, problems that faced by farmers. This strategy works well in improving the rural/ecovillages' sustainabilityfor the sub-aspect of communication and information, although in fact only6 percent of farmers that use the Internet.

The sub-aspect of the network and services shows progress toward sustainability with a score of 91.7 percent (Table 9). The indicators of the networks and services include, among others, the availability of information on pig farms, the farmers' involvement in the provision of services, and the availability of the opportunity to establish a relationship with extension workers. Information about theserasah system for pig farming has been available to the public for some time, because this system of pig farming is already well known in Wonosobo Regency. In addition, 93 percent of the farmers stated that information about the existence of training for farmers by field extension workers is also available to the public, but 7 percent stated they rarely have information about training by field extension workers. Farmers claim 70 percent of them provide helpers to other farmers and there are also pigsties available to rent under theserasahsystem for members of the community or farmers who want to keep pigs, while 84 percent of the farmers report working together to help each other in overcoming problems in theirpig raising activities. In addition, farmers are also often involved with activities organised by their village governments, such as getting involved in elections, so that the network of services performed is quite extensive.

The sub-aspect of social sustainability shows progress toward sustainability with a percentage figure of 82.8 percent being recorded (Table 9). This sub-aspect includes discussions about diversity and tolerance, decision making, and problem solving. Diversity is respected as a source of health, vitality and creativity in the natural environment, and for the farmers and their community's relations. Acceptance, closure and openness foster an understanding of the benefits of diversity, enriching experiences and supporting social and environmental justice.

Cultural tolerance of theserasah system pig farms is not a problem, they are tolerated because pig farming is already part of the culture of the local villages and almost all the people either work for, or are, pig farmers under theserasah system. Religious diversity is not visible, because the religion professed by all the farmers and the society they live in is Islam. However, the farmers and local people still have respect for diversity and tolerance towards other cultures and religions. This is evidenced by the farmers openness to the world outside their villages. The farmers do not shut themselves off from the technology and cultures brought in by extension workers while still maintaining the culture of the serasah system pig farms. Technology and culture brought by 
extension workers in the form of bio-activator that accelerates the biodegrading of faeces into compost, and the farmers happily accept the new technology. Therefore, conflicts rarely occur in the community. The decisions that relate directly to a farm will be resolved through discussions with the relevant parties.

The sub-aspect of education shows progress toward sustainability with a percentage of 87.6 percent (Table 9). It covers the education of the farmers, both formal and non-formal. The expected conditions of personal growth, learning and creativity are valued and nurtured, opportunities for teaching and learning are made available to all age groups through various educational formats. In certain cases, the farmers ask for and respect the input and contribution of older farmers, exchanging information with them from time to time.

The levels of education of the farmers spans from no schooling at all to college attendance. The higher the level of the education of the farmers is, themore receptive they are to technological innovations that can serve for the betterment of their businesses. The number of pig farmers with an elementary school level education is relatively high, they can hardly be expected to improve their farms by themselves, but the local governments do already provide socialization and practical help in the form of skills/specialized expertise to improve the human resources of the farmers. Mardikanto (1993) argues that the farmers or people with high human resources will be innovatorsand accepting of new technological innovations.

The sub-aspect of the sustainability of the local economy shows a promising start toward sustainability with a figure of 60.7 percent (Table 9). According to Sunarti (2009), in developing an economic perspective for the agricultural sector, the focus is on a few things: The availability of production factors and raw materials which are environmentally sound, including for the waste management system, the strengthening of marketing agencies and financial institutions, the strengthening of the farmers' groups, agricultural developments integrated into the social system present in the area, and infrastructure development.

The value of manure becomes a major factor for theserasah system pig farms, because if they only rely on selling the meat, the serasah system pig farms run at a loss, because under this system the daily weight gain of an animal is only $274 \mathrm{~g}$ /day after being weaning, while commercially reared pigs gain $513 \mathrm{~g} /$ day, nearly double that of a pig farmed under theserasah system (Hartoko, 1988).

The main expected outcomes of farmers in the Serasah system pig farm is pig manure litter to be sold as compost, instead of the pig itself. Pigs are reared in sties throughout the year to allow for the collection of all their faeces and its composting. The selling of pigs is not really preferred because of the emphasis on the production of their faeces. Pigs may be for sale if there are any buyers, but farmers sometimes refuse to sell. Most of the buyers of the pigs come from Temanggung Regency, and the animals are sold at a live weight price of Rp 22,500/kg. They are not slaughtered before sale, but only when they reach Temanggung Regency, where there are slaughterhouses.

Various plants such as tobacco and vegetables show considerable potential for being farmed in Kertek District. The use of compost to aid tobacco and vegetable crops growth, obtained from the serasahmethod of pig farming, is relatively high, providing motivation to the farmers to keep raising pigs under theserasah system. This serasah compost sells for Rp 1,200/kg but if at least $30 \mathrm{~kg}$ is purchased then the price drops slightly to $\mathrm{Rp} 1000 / \mathrm{kg}$. All the compost produced by thisserasahsystem is sold for agricultural use, generally to tobacco farmers and vegetable growers.

The pig population in the Kertek District is 2,135 animals (Central Agency of Statistics, Wonosobo, 2014).It is calculated that three pigs can produce three rit (a rit is the term used to refer to a four-wheel truck) and can produce as much as 712 rit of serasah composting 4 months, or 2,278 tons in 4 months, as 1 rit equals $3,200 \mathrm{~kg}$, and thus in one year they can produce approximately 6,834 tons of serasahcompost with a value of Rp $8,200,800,000 /$ year.

Serasah compost is used for dryland agriculture (tobacco, coffee, and vegetables) requiring 20 ton/ha, except if used rice when 5 ton/ha is enough. Based on data from theCentral Agency of Statistics, Wonosobo (2014), 2299.32 ha of the land in Kertek District is used for agriculture, which constitutes $37 \%$ of the area of thedistrict. Serasah compost production, according to rough calculations, is about 6,834 tons/year. Based on these calculations, the amount of compost produced under theserasahsystem can only be used to fertilize a dry land area of 341.7 ha or 14.86 percent of the dry land area used for agriculture.This is an indicator that the serasah system of pig farming is not yet at its optimum and can be improved further because there are still 85.14 percent or 1957.62 ha of dry land that needs to be fertilized with serasahcompost.

\section{Conclusion}

Pig farming under the serasah system in District Kertek, Wonosobo Regency, Indonesia does not negatively 
impact community development as shown that ecological aspect indicates "a good start towards sustainability"and socio economic aspect shows "progress towards sustainability". Therefore, pig farming under the serasah system has good sustainability. However, farmers need assistance both from government / university through extension workers to improve their knowledge in managing water resources, communal resources and waste management system.

\section{References}

Bagoes, M. I. (2000). Langkah Penelitan Survei Usulan Penelitian dan Laporan Penelitian. Badan Penerbit Fakultas Geografi UGM. Yogyakarta.

Brown, H. D. (2001). Teaching by Principles. Addison Wesley Longman, Inc. San Francisco.

Central Agency of Statistics Wonosobo. (2014). Kecamatan Kertek Dalam Angka. Central Agency of Statistics. Wonosobo. Central Java.

Chan, D. K. O., Chaw, D., \& Lo, C. Y. Y. (1994). Management of the sawdust litter in the 'pig-on-litter' system of pig waste treatment. Resources, Conservation and Recycling, 11, 51-77. https://doi.org/10.1016/0921-3449(94)90078-7

Cooper, D. R., \& Schindler, P. S. (2011). Business research methods. McGraw-Hill International Edition.

Department of Animal Husbandry Wonosobo Regency. (2014). Populasi Peternakan di Kabupaten Wonososbo. Department of Animal Husbandry. Wonosobo. Jawa Tengah.

Frick, H., \& Suskiyatno, F. X. B. (2007). Dasar-Dasar Arsitektur Ekologis:Konsep Pembangunan Berkelanjutan dan Ramah Lingkungan. Kanisius. Yogyakarta.

Gay, L. R., \& Diehl, P. L. (1992). Research Methods for Business and Management. MacMillan Publishing Company. New York.

Global Ecovillage Network. (2000). Community Sustainability Assessment. Five E’s Unlimited. Europe.

Hartoko. (1988). Peternakan Babi Rakyat dengan Pemeliharaan dalam Kandang Serasah. Fakultas Pasca Sarjana IPB. Bogor.

Kirby, A. (2003). Redefining social and environmental relations at the ecovillage at Ithaca: a case study. Journal of Environmental Psychology, 23, 323-332. https://doi.org/10.1016/S0272-4944(03)00025-2

Luxy, M. J. (1999). Metodologi Penelitian Kualitatif. Remaja Rosdakarya. Bandung.

Makermann, A., Stemmer, A., Siegmund-Schultze, M., Piepho, H. P., \& Zárate, A.V. (2009). Stated preferences of llama keeping functions in bolivia. Livestock Science, 124, 199-125.

Mardikanto, T. (1993). Penyuluhan Pembangunan Pertanian. UNS Press, Surakarta.

Ministry of Agriculture. (2014). Populasi Peternakan di Indonesia. Direktorat Jenderal Peternakan. Ministry of Agriculture Indonesia: Jakarta.

Sihombing, D. T. H. (2006). Ilmu Ternak Babi. Gadjah Mada University Press. Yogyakarta.

Simond, J. O., \& Starke, B. W. (2006). Landscape Architecture, a manual of environmental planning and design (4th ed.). New York: Mc Graw-Hill.

Soepraptohardjo, M. (1976). Jenis Tanah dan Kemungkinan PengenalanKapabilitasnya dari Potret Udara. Departemen Pertanian, BadanPenelitian dan Pengembangan Pertanian, Lembaga Penelitian Tanah. Bogor.

Sudradjat, H. R. (2006). Mengelola Sampah Kota. Penebar Swadaya. Jakarta.

Sukawi. (2010). Kaitan desain selubung bangunan terhadap pemakaian energi dalam bangunan (Studi kasus perumahan graha padma Semarang). Fakultas Teknik UNDIP. Semarang.

Sunarti, E. (2009). Pengembangan Kawasan Perdesaan serta Peningkatan Sumbangan Pertanian bagi Peningkatan Kualitas Hidup Penduduk Pedesaan. Fakultas Pascasarjana IPB. Bogor.

Watt, I., \& Michell, F. (1989). Pigs and Poultry in The South Pasific (1st ed.). Sorret Publiching Pty. Ltd. Victoria.

\section{Copyrights}

Copyright for this article is retained by the author(s), with first publication rights granted to the journal.

This is an open-access article distributed under the terms and conditions of the Creative Commons Attribution license (http://creativecommons.org/licenses/by/4.0/). 